\title{
The story of the Red Sea as a theological fRAmework of INTERPRETATION
}

Authors:

Young M. Song ${ }^{1}$

Jan A. du Rand ${ }^{2}$

\section{Affiliations:}

${ }^{1}$ Kosin University, Kosin, South Korea

${ }^{2}$ Department of Biblical Studies, University of Johannesburg, South Africa

Correspondence to:

Jan du Rand

e-mail:

jdurand@uj.ac.za

\section{Postal address:}

Department of Biblical

Studies, University of

Johannesburg, PO Box

524, Auckland Park,

Johannesburg, 2006,

South Africa

Keywords:

Red Sea; interpretation; theological framework; exodus motif; salvational acts of God

\section{Dates:}

Received: 08 Dec. 2008

Accepted: 12 Mar. 2009

Published: 16 Dec. 2009

How to cite this article: Song, Y.M. \& Du Rand, J.A., 2009, 'The story of the Red Sea as a theological framework of interpretation', Verbum et Ecclesia 30(2), Art. 337, 5 pages. DOI: 10.4102/ ve.v30i2.337

\section{This article is available} at:

http://www.ve.org.za

Note:

This article was

delivered as a paper at

the International SBL

meeting in Auckland

New Zealand, 2008, as a result of Y.M. Song's DLitt et Phil thesis: 'A partial preterist understanding of Rev 12-13 in intertextual perspective', supervised by Prof Jan A. du Rand, Department of Biblical and Religious Studies, Faculty of Humanities, University of Johannesburg.

(C) 2009. The Authors. Licensee: OpenJournals Publishing. This work is licensed under the Creative Commons Attribution License.

\section{ABSTRACT}

The exodus motif is widely agreed to be one of the central frameworks illustrating the salvational acts of God in both the Old and New Testaments. According to the Old Testament, the exodus motif was, to Israel, the paradigm of redemptive historical renewal. For this reason, the exodus motif provided the typological expression for all future hope of salvation and served as a theological paradigm to be used by Old and New Testament authors. In this article, the exodus theme in the Book of Revelation, chapters 12 to 13, is discussed in the following order: (1) Christ's crucifixion and resurrection as the archetypal exodus; (2) the chronological fulfillment of the exodus theme in the Bible; and (3) the exodus theme in Revelation 12 to 13 . To investigate the exodus theme in Revelation 12 to 13, the intertextual interpretation, as based on the redemptive historical interpretation, will be highlighted.

\section{INTRODUCTION}

\section{Christ's crucifixion and resurrection as the archetypal exodus}

The focus of the first section of the article is on the Gospel according to Luke, since Luke prominently introduces the 'exodus' of Jesus (Lk 9:31). Broyles (1992:561-562) correctly interprets Luke's understanding of the transfiguration, suffering and resurrection of Jesus as related to the exodus theme. Such peculiarities can be summarised as follows: only Luke records that Moses spoke with Jesus of his impending exodus from Jerusalem. The Passover lamb, whose bones are not to be broken (Ex 12:46) and the blood of the Covenant (Ex 24:8; cf. Lk 22:20) foreshadow Jesus' sacrificial death, although no explicit reference to the person of Moses is made.

In the central section of Luke (9:1-50), Jesus recapitulates and fulfils the Exodus, similar to the prophet Moses in Deuteronomy (cf. Garrett 1990:12). The textual context of Luke 9:1-50 shows that the 'exodus' of Jesus is the watershed and pivotal focus of the entire narrative. Just before the journey to Jerusalem, Jesus announced his exodus (Lk 9:51). Such timing parallels the Exodus in its preceding the journey to the promised land of Canaan. Jerusalem, as the new Canaan, is the promised location of the Holy Spirit as an eschatological gift (Lk 24:49) and the central location of God's redemption of Israel and the Gentiles (Ac 1:8). By means of the above-mentioned typology of Moses and the exodus theme, it is clear that Luke intends to reveal the suffering, resurrection and glorification of Christ, not only as the second Moses, but as the One greater than Moses (cf. Garrett 1990:659). The points of contact between Moses and Jesus, mentioned in Luke, are points of continuity in terms of redemption. ${ }^{1}$

\section{The chronological fulfilment of the exodus theme}

The collective memory of the Exodus from Egypt shaped accounts of God's past acts of redemption, and provided, in a typological sense, a framework for all future hope (cf. Garrett 1990:656). The Old and New Testament prophecies and covenants are fulfilled spirally, rather than in a linear fashion (cf. Goldsworthy 1991:76, 92). In other words, such fulfillment is a progressive duplicate. At this stage of the article, the fulfillment of the exodus theme will be traced in chronological order, by means of referring to selected glimpses of several important redemptive historical events. It will be demonstrated that the fulfilment of the exodus theme is to be noted both in the Exodus, and in the post-Exodus periods.

\section{The pre-Exodus period}

During the period of the patriarchs, the exodus theme appears in the form of a shadow. Abraham's return with spoils from Egypt provides a foretaste of Israel's Exodus, which is led by Moses. The 'exodus' of Joseph's bones into Canaan can be understood as occurring within the same context. The Covenant of Abraham and of the patriarchs was the main motivation for the Exodus (Ex 2:24-25; cf. Lk 1:55). Several similarities between the story of Jacob and the exodus theme come to light: (1) In several texts, Jacob's departure from Laban is understood in terms of the release of a slave. (2) For example, the two verbs 'to drive out' and 'to send' are common and characteristic terms of the exodus (Ex 6:1; cf. Lk 1:51). (3) Jacob, together with the Israelites, returned to his homeland Canaan with a wealth of possessions (Ex 12:36). (4) The division and separation themes appear in both accounts (Gn 30:40). (5) Military terminology is evident in both texts (Gn 32:2; Ex 12:41; Lk 1:51-52). (6) A change of identity takes place in both the Old Testament and the New (Gn 32:28; Lk 1:48). (7) Service to God is emphasised in both Genesis and Exodus (Gn 35:14-15; Ex 8:1) (cf. Daube 1979:63-64).

\section{The period of the Exodus led by Moses}

The Exodus led by Moses, which functions as an antitype, is a fulfilment of the events in the pre-Exodus period. The Exodus itself functions as a pattern or paradigm for the later salvific acts of God. Thus, the consummation, as well as the fulfilment, of the Exodus in the person and works of the new Moses,

1.When searching for the exodus theme in the Four Gospels, it is useful to compare Moses, who, as the representative of Israel, directly received the OT law on Mount Sinai, with Jesus Christ, who, as the lawgiver, proclaimed the law of the eschatological kingdom of God. Christ, as the inaugurator of the new Covenant, conveys the true meaning of the OT (in the Johannine term 'truth'; cf. Lk 24:44). The exodus theme in the Gospels is an important theological framework in which the typology of Moses and Jesus comes to the fore, as it
entist exodus theme in the Gospels is an important theological framew
sheds light on the redemptive death and resurrection of Christ. 
Jesus Christ, remain valid. The fact that the Exodus from Egypt exemplifies a holistic salvation, which includes both physical and spiritual aspects, foreshadows the holistic redemption attained in Jesus. The Exodus led by Moses is the true and legitimate beginning of the eschatological exodus theme.

\section{The period of the Judges}

The return of the ark from the Philistines during the time of judge Samuel (1 Sm 6:6-21) is redolent of the exodus theme, in that the event recalls the Exodus. Several parallels exist between the return of the ark from the Philistines and the exodus motif: (1) God punished both the gods of Egypt and those of the Philistines (Ex 12:12; $1 \mathrm{Sm} \mathrm{5:3-4).} \mathrm{In} \mathrm{other} \mathrm{words,} \mathrm{the} \mathrm{ark} \mathrm{was} \mathrm{not} \mathrm{welcome}$ to the god Dagon. (2) God punished the Philistines by inflicting tumours on them (Ex 9:10; $1 \mathrm{Sm}$ 5:6). (3) The notion of service to God is evident (1 Sm 7:3). (4) Similar words, such as 'to smite' (Ex 9:15; 1 Sm 5:12) and 'plague' (Ex 9:14; 1 Sm 6:4), can be seen in both accounts (cf. Fretheim 1991:387)

(5) Moses and Samuel are comparable in terms of their leadership of Israel (1 Sm 7:6-9, 15) (cf. Daube 1979:73-74). By recalling the Exodus led by Moses, the return of the ark during the period of the Judges is related to its return during the time of David. In addition, the return of Ruth's family from Moab can also be understood in terms of the exodus theme.

\section{The period of King David}

The Exodus and the Davidic covenants relate to each other: (1) God performed great wonders to rescue his people (2 Sm 7:2324). (2) God drove nations (such as Egypt) and their gods away from his people. The Davidic covenant, accordingly, not only relates backwards to the Exodus, but also forwards to the eternal Messianic kingdom of the future.

\section{The periods of the pre-Babylonian and the post- Babylonian exile}

\section{The period of the pre-Babylonian exile}

As Collins (1995:156) claims, apart from Amos (Am 2:10; 9:7), Micah is the only prophet to recite all that God as the Lord of the world did for Israel during the Exodus, after which he refocuses on the person of the worshipper. During the period of the preBabylonian exile, some prophets recalled the Exodus in their proclaiming of both the leading of a moral life and the practising of true worship as the appropriate lifestyle for the people of God. Indeed, the Exodus imposes certain moral obligations on the lifestyle which is required to be led by the people of God. In this instance, the Exodus also functions as a paradigm for the preexile prophets. Even during this period of pre-exile, the exodus theme reveals the scope of universalism. Moreover, the airing of the exodus theme gave birth to the norms of the Israelites who lived as the people of God during the pre-exile period.

\section{The period of the post-Babylonian exile}

In Isaiah, the hope of deliverance from exile is referred to, both in terms of the Exodus and also in anticipating the Messianic salvation (Is 42:1). The Abrahamic Covenant provided an important motivation for liberation from exile (Is 41:8; cf. Collins 1995:157). The central themes of both Hosea and Ezekiel are phrased in terms of the reminiscences of the Exodus. Hosea provides the assurance that God will renew his Covenant by again leading his people through the wilderness (Hs 2:14-20). The Exodus furnishes evidence of God's love for Israel (Hs 11:1; Ezk 20). In post-exile times, the prophets considered Israel's breach with God's norms, which, in a sense, derived from the Exodus, as the reason for the Babylonian exile. ${ }^{2}$

\footnotetext{
2.The Book of Esther should be kept in mind, because Esther functions with the exodus framework in the background. Though every detail of the exodus pattern is not present in every instance of it, and there are twists in the way in which the pattern is presented, the pattern is always obvious and clear. The following is the sequence, as applied to Esther (see Jordan 1996:1-4):

(1) Some threat, some aspect of sin or of the curse, drives God's people from their home. The sins of Israel drove the Jews into exile in Babylon, which became Persi (2) During the sojourn in captivity, Eve (i.e. the exiled Jews) is assaulted by the
}

The period of Jesus Christ

Dillard and Longman rightly claim that

many parallels are drawn between the Exodus and Christ's earthly ministry, particularly during his passion. Jesus went to the cross during the time of Passover. Christ fulfilled the Exodus during his earthly ministry.

(Dillard \& Longman 1994:66)

In fact, Jesus has recreated the new Israel through the restoration that he achieved in his person and works. In a certain sense, the Old Testament Exodus and the later salvations were confined to the restoration. This is proven by the focus on the verbs 'to return' and 'to restore' (1 Ki 13:3; Job 33:25; Hs 6:1). Jesus is the leader or the redeemer of a new and final exodus, through which God initiated his trans-historical plan, such as the new Messianic era. The coming, the person, and the works of the Messiah decisively fulfill all the previous exodus themes and implicitly embody their consummation ( $c f$. Kim 1997:636).

The period of the Apostles and the Early Church During the period of the Apostles and the Early Church, the exodus theme can be understood in terms of the suffering, resurrection, and glorification of Christ. The archetypal exodus of Christ legitimates the exodus of the Early Church. This is demonstrated by Garrett (1990:670-680), who compares the rescue of Peter (Ac 12:1-24) with both the resurrection of Jesus (Lk 9:31) and the exodus. Garrett identifies several similarities in such texts: (1) Peter's imprisonment and rescue take place at Passover (Ex 12; Ac 12:3-4, cf. Lk 22:1-2). (2) The concept of ' $[\mathrm{g}]$ etting up quickly' (Ac 12:7) is closely related to the term 'raise up', which is used to describe God's action of raising Jesus from the dead. (3) The sequence of events after Peter's escape recalls the events immediately following on Jesus' resurrection (Ac 12:13-14; cf. Lk 24:11). (4) The angel's command to Peter to 'dress yourself and put on your sandals' (Ac 12:8) recalls God's instructions to the Israelites in Exodus 12:11. (5) The description in Acts 12:11, 'rescued me from the hand of Herod' runs parallel with that of the deliverance from the hands of the Egyptians (Ex 3:8). The above similarities demonstrate that the deliverance of Peter enacts the meaning of Jesus' resurrection (i.e. the archetypal exodus)

The development of the redemptive revelation history illustrates the fulfillment of the exodus theme in Jesus Christ. God has properly applied, and has repeatedly fulfilled, the exodus theme in every period by means of one great watershed, namely the cross and resurrection of Christ as the decisive fulfillment of the

(footnote 2 Cont..)

Serpent, who wishes to use her to raise up his own wicked seed. While nothing is said about Ahasuerus desiring children from Esther, he does take her into his harem because she is beautiful, the same reason Pharaoh took Sarai from Abram in Genesis 12 (one of the earliest exoduses). In the Esther events, though, there is a twist: the 'attack' on Eve is not really an attack at all, but rather something Mordecai and Esther cooperate with.

(3) The righteous use 'holy deception' to trick the serpent and protect Eve. Esther tricks Haman into thinking he is going to be honoured, and in a way tricks Ahasuerus into a situation where he is confronted with Haman's perfidy.

(4) Very often, God's people are enslaved during the sojourn outside the land. In a strict sense, that is not the case in this instance.

(5) God brings blessings upon his people during the captivity, but plagues the tyrant, (5) God brings blessings upon his people during the captivity, but plagues the tyran either progressivly or as part of the delin duce. Haman notes that the Jews have the blessing of keeping their own laws in the empire of Persia. The destruction of Haman is the plagues on the tyrant.

(6) God miraculously intervenes, often with visions to the pagan lord, in order to save his people. The dream given to the pagan lord during the night is, in this case Ahasuerus' sleepless night during which he is read the chronicles of his reign, and determines to bless Mordecai.

(7) Very often the serpent tries to shift blame and accuses the righteous man of being the cause of the difficulty. In Esther 3 Haman insinuates to Ahasuerus that the Jews are troubling his empire.

(8) God humiliates the false gods of the enemy. Haman clearly has his own gods; in fact, when he boasts of his glory and praises his own accomplishments, Haman seems to be his own god (Es 5:11).

(9) God's people depart with spoils. Since God wanted the Jews to be 'spread out as the four winds' within the empire, no geographical departure was needed.

(10) On the way, God's people are attacked (Ex 17; $1 \mathrm{Sm} \mathrm{15).} \mathrm{Cyrus} \mathrm{has} \mathrm{let} \mathrm{the}$ (10) On the way, God's people are attacked (Ex 17; $1 \mathrm{Sm} 15)$. Cyrus has let the the Agagite.

the Agagite.

(11) Finally, God's people are installed in the Holy Land. Such installment means building God's house out of some of the spoils. The Jews did not take the spoils for themselves, but set them aside for God. 
theme. Therefore, each fulfillment in every period has naturally to be connected to Christ, whether explicitly, implicitly or even partially.

\section{The exodus theme in Revelation 12-13 The exodus theme in the Book of Revelation ${ }^{3}$ in general}

In the Book of Revelation, the soteriological message is anchored in Jesus Christ's eschatological salvific works and is aligned with the blessings which his saving work brings to the universal Church, as well as to the whole of creation (Du Rand 1993:310). According to Jenkins (1972:68, 71), John alludes to the Book of Exodus 27 times, particularly in emphasising the event of the Exodus itself. John draws images from the past redemptive work of God (i.e. the Exodus) and presents them anew as the vehicle of the present moment to encourage his community to endure those persecutions to which they are being subjected.

Many obvious parallels between Exodus 15 and Revelation 15 are important: (1) The theme of victory in Exodus 15 becomes the basis for praise in Revelation 15:3-4 (Mounce 1983:287). (2) Several Exodus terms, such as 'glory', 'victory', and 'tabernacle' are used in both texts ( $c f$. Ex 15:11; Rv 15:4). (3) The entire scene of Revelation 15:2 revives the memory of the Israelites standing on the shore of the Red Sea. (4) The seven plagues (Rv 11:6;15:8) recall the ten plagues which were inflicted on Egypt. (5) The universal recognition of Jahweh as the one true God (Ex 15:14; $\operatorname{Rv} 15: 4$ ) is a common theme (Mounce 1983:288).

All those redeemed on earth shall stand at the sea of glass to join the victorious crowd in singing the song of Moses and of the Lamb ( $\operatorname{Rv} 15: 3)$, with their song, therefore, combining the imagery of both the Old and the New Testament. Moreover, the multitudes ( $\operatorname{Rv} 15: 2)$ also sing about the fulfillment of all the prophecies, in that all nations shall fear God and glorify his name (cf. Hoeksema 1974:522-526). The implication is that the nation of Israel in the Old Testament already sang the song of the Lamb, with the people of the Lamb in the New Testament also singing the song of Moses (cf. Du Rand 1997:273). Thus, the song of Moses is theologically congruent with the song of the Lamb. The old and the new dispensations both sing about the same message: God's salvation.

The three songs in Revelation 19:1-8 emphasise the fulfilled salvation and the triumphant kingdom of God, despite the constant threat posed by Christ's enemies. The martyrs praise the characteristics of God, namely his truth and righteousness, which accord with his works (Rv 19:2). Jesus fulfills the role of the Paschal Lamb (Is 53:7), causing the triumphant redeemed to sing 'the Hallel [i.e. Hallelujah] Psalms' (Ps 113-118, cf. Ex 15:21; Rv 19:1,3,4,6). In John's contemporary context, the jubilant proclamation of 'Hallelujah! The Lord our God the Almighty reigns' (Rv 19:6) strongly affirms God's absolute sovereignty, which recalls the punishment that was imposed on the Egyptian gods (Ex 12:12; Boring 1986:257). In short, John's first readers, who formed part of the new Exodus community, must have been encouraged by the singing of such songs.

\section{The exodus theme in Revelation 12-13}

The provision by the exodus theme of a theological framework for New Testament authors, including John, should be seen in the light of the relevance of Revelation 12-13 for the exodus motif. John offers a view to the oppressed Christians in Asia Minor in the form of a symbol derived from the Exodus experience of deliverance and liberation. In particular, John aims to convince his audiences that they comprise the community of the new Exodus.

3.In their recent commentary on the NT use of the OT, Beale \& McDonough (2007:1082) Isaiah, Ezekiel, and Daniel. They also agree that the accounts of the plagues in Exodus are the source of some of the most startling imagery in Revelation. In addition, the theme of liberation from oppressive rulers is the predominant motif in Exodus and Revelation.
John associates the dragon ( $R v$ 12:3) with Egypt and Rome or Jerusalem, since the Old Testament metaphors of the sea monster predominantly portray Egypt as an opponent of God's people (Ps 74:13-14; 89:10; Hab 3:8-15). John sees (Rv 12) a repetition of the exodus pattern (Beale 1999:633). When he narrates how the dragon appears in heaven, he describes it as 'red'. This is the only instance in the whole Bible where the dragon is referred to as being of that colour. The red dragon is reminiscent of the Red Sea of the Old Testament, which should have indicated to John's audiences that, although the dragon is awe-inspiring, God will surely overcome it. In line with the long tradition of the Jewish people, Jewish audiences would immediately have understood God's impending overthrow of the dragon, as soon as John said that it was red (Kio 1989:131). The key incident in Revelation 12:4 to which the idea corresponds, and in which it is realised, may be found in Pharaoh's efforts to destroy the infant Moses (Miligan 1889:202).

The woman's flight to the wilderness is described in terms of an exodus ( $\operatorname{Rv} 12: 6,13)$. The desert $(\operatorname{Rv} 12: 6,14)$ is a common symbol in both the Old and New Testaments for a place of God's protection while waiting for the fulfillment of his promises. Even the eagle's wings ( $\operatorname{Rv} 12: 14)$ make patent reference to Exodus 19:4 and Deuteronomy 32:10-12, in which the wings of the eagle are a symbol of God's protection and providence ( $c f$. Mazzaferri 1989:371). In Revelation 12:14 the combination of the exodus theme and the re-creation theme is emphasised. White correctly articulates the point as follows:

John's allusion to especially Dt. 32:10-11 is significant, for in the text Moses compares God's presence with Israel in the wilderness to God's presence at creation in Gen. 1:2. That Moses does in fact make this comparison is signalled by two points. On the one hand, the typical verb used to describe God's activity in Dt. 32:11 occurs again in the Pentateuch only when Moses describes the Spirit's activity at creation in Gen. 1:2b. On the other hand, the noun used to describe the wilderness where God accompanied Israel in Dt. 32:10 occurs again in the Pentateuch only when Moses describes the state of the earth over which the Spirit hovered at creation in Gen. 1:2a. From these lexical parallels it is not difficult to see that in Dt. 32:10-11 and Ex. 19:4 Moses interprets the Exodus event as a redemptive re-enactment of creation, indeed as Israel's redemptive re-creation. When John alludes to those texts in Rev. 12:14, it is no more difficult to see that he understands the woman's experiences as her participation in the new Exodus under the Lamb. ... John is also telling us that the woman's participation in the Messianic Exodus entails her redemptive re-creation.

(White 1989:117-118)

Apart from the purely metaphorical meaning of God's protection, in terms of the allusion made in Exodus 19:4 to 'bearing you on eagle's wings', such imagery may also be political in nature. In Egypt, the vulture goddess Nekhbet represented Upper Egypt, protecting both Pharaoh and the land. Nekhbet, who was depicted as being particularly maternal, was believed to assist at royal and divine births. Her temple in el-Kab was worked on extensively during the reign of the Eighteenth Dynasty, toward the end of the Israelites' captivity in Egypt, indicating that she was a popular goddess at the time. In Egypt, God protected the Israelites, as can be seen in both Exodus 19:4 and Deuteronomy 32:11, which speak of the Lord's care and protection of his people, in terms of imagery reminiscent of the Egyptian metaphors of care and protection (Walton \& Matthews 1997:106,267).

In terms of the exodus motif, blood (Rv 12:11) serves as a seal of protection and safety. In contrast, blood, as a symbol of death, binds both God and the people together as one in partnership in the Covenant seal (Ex 19:4-6; 24:3-8; Kio 1989:134). Although John's clear intertextual references to the Exodus cannot be denied, it should be noted that White points out the difference between the victory in Revelation 12:11 and the victory that was experienced during the Exodus of the Old Testament:

The great irony of Israel's victory over the dragon (Egypt) had been that, though they were released from Egypt, they were not 
released from their sins. Therefore, through the law given to Israel in their continuing bondage to sin, God could accuse them of sins and by his indictments subject them to the curses of defeat and death. The saints' victory over the dragon, however, is profoundly different. As depicted in Revelation 12:10-11, the holy seed is still accused of sins, but they are accused by the dragon, not by God.

(White 1989:114)

Hanson (1993:226) captures the significance of the allusion to blood ( $\operatorname{Rv} 12: 11 ; c f . \operatorname{Rv} 7: 14 ; 19: 13)$ in terms of the pure-impure social system. He compares Revelation with Leviticus: In contrast to the Aaronic priesthood, who must use animal blood within the confines of a sanctuary, the Lamb's $\mathrm{s}^{4}$ blood accomplishes redemption for all, creating a new community, in which all members are, at least symbolically, priests (Rv 5:9-10; 7:14). The image of the blood of the Lamb also reverses the categorisation of blood on garments in Leviticus 6:27. Instead of being a source of pollution, the Lamb's blood becomes a metaphor of purification, when the saints and the Word of God wash their robes in it (Rv 19:13-14; cf. Lv 7:14; 19:13).

Embedded in the exodus motif, John also uses the eagle metaphor' (Rv 12:14), which was familiar to his audience in Asia Minor as a symbol of the Roman army. John uses the metaphor in order to accentuate the fact that it is not Rome, but God, who protects the seven churches in Asia Minor. As Sweet (1990:203) notes, the model for her flight ( $R v 12: 14)$ is the Exodus story. God brought his people on eagle's wings into the wilderness (Ex 19:4). ${ }^{5,}$, The river-flood (Rv 12:15) evokes Pharaoh's attempt to destroy male Israelites in the river (Ex 1:22), as well as his pursuit of the Israelites in the gap created in the waters of the Red Sea (Ex 14:21; cf. Beale \& McDonough 2007:1126).

Revelation 12:16 may be linked to Exodus 15:12: '...You stretched forth your right hand, the earth swallowed them up... (Minear 1991:76). The '...earth opening its mouth...' (Rv 12:16) also calls to mind the destruction of Korah in Deuteronomy 11:6 '... the earth opened its mouth and swallowed them...' (cf. Gn 4:1-16; Nm 16:30-33). The earth's protection of the woman in Revelation 12:16 ironically reverses the earth's endangerment of the remaining Israelites in Numbers 16:34 and Deuteronomy 11:6. Although John freely uses and alters the exodus motif, the results of the new Exodus are the same as those of the old: the mother of the seed, as it were, walks on dry land through the midst of the waters (Ex 15:19; cf. White 1989:118)

When John records the dragon's rage over the woman's escape, and his leaving of her to wage war against the rest of her seed in Revelation 12:17, he characterises such seed as those 'who keep the authoritative instruction of God and hold to the testimony of Jesus' (cf. Rv 14:12). The phrase 'obey God's commandments' bears a theological intertextuality to Exodus. During the time of the Exodus, the Israelites' obedience to God's commandments would have signified the victory of the nation over sin, the sequel to which would have been her re-creation as God's holy kingdom ( $c f$. Rv 1:5-6). The phrase describing the seed's keeping of God's authoritative instruction (i.e. his Commandments) in Revelation 12:17, indicates the seed's re-creation as the kingdom constituted by the Lamb. In fact, the salvation of John's audience surpasses that of Israel: unlike the nation of Israel, his audience would have been constituted as God's kingdom not simply by divine precept, but also by divine power (White 1989:120-121).

4. The idea of a lamb being offered as a cultic sacrifice certainly contributes to this imagery. One should not over hastily interpret the lamb image as being solely, or even primarily, part of cultic-sacrificial terminology (see Reddish 1995:215).

5.Instead of the second person plural pronoun of MT, the translators of LXX use the third person, which is short for 'you yourselves' with the meaning of 'you have seen what I have done'. In the past, the Israelites had taken note not only of the salvific wht but also of God's bringing them as on eagles' wings, meaning that they soared with between God and his people was formally enacted (see Wevers 1990:293-294).

6.Compare Dt 32:11: 'eagle's wings' with Rv 12:14, where God's people were nourished for 42 years.
Revelation 13:4 might be a parody of Exodus 15:11, in the sense that the beast's victory over death is paralleled with God's victory over the Egyptians (Kraft 1974:272). In terms of such thinking, the dragon's sending of the two beasts ( $R v$ 13:1,11) would correspond with the test inflicted at the hands of Balak and Balaam, ${ }^{7}$ whom the Israelites encountered upon their entry into the promised land (Sweet 1990:203). The rhetorical question, 'Who is like the beast?' ( $\operatorname{Rv} 13: 4)$ echoes the type of language that was frequently used to praise God in biblical times, such as 'Who is like you, Lord, among the gods' 8 (Ex 15:11; cf. also Ps 35:10; 113:5; Beckwith 1967:636). Following on the rhetorical question 'who is like the beast, and who is able to wage war against him?', three aspects of Yahweh's incomparability are raised in a further rhetorical question: his magnificent holiness; his praiseworthy deeds; and his extraordinary accomplishment. Thus, John reminds his audience of the strong contrast between the true God and the beast, urging them to remain faithful to the incomparable God.

The temple motif is also an important part of the exodus theme in Revelation 13:6. The fellowship and residence of God in the tabernacle in the historical Exodus event (Ex 40:34) foreshadow God's dwelling and fellowship in the true temple, which is embodied in those believers who experience the new Exodus in Christ (cf. Rv 21:3). The Exodus, which was led by Moses, is not only transformed into a form of new exodus by Christ, but is also a form of deliverance from exile. So, the exodus led by Jesus is the archetype of the consummated salvation of God in future, as well as the antitype of the Exodus led by Moses.

In Revelation 13:8 (as well as in Rv 5:6, 9,12), John uses the word 'slaughter' for 'slain'. Since 'slaughter' refers to the violent death of the lamb slaughtered in sacrifice (Ex 12:6), the image evokes the memory of Israel's Exodus and liberation from Egypt which was considered in Judaism as a prototype of the final eschatological salvation (Kio 1989:132-133).

The mark of the beast in Revelation 13:17 (cf. Rv 14:9b), which signifies that those marked in this way belong to the beast, is equated to the sign in Exodus 13:9,16. Both books define the mark as a proof of possession (Kio 1989:126). Another echo of the mark that is first described in Exodus consists of the first plague of the seven bowls in Revelation 16:2, which appears as 'an ugly and painful sore' on those who bear the mark of the beast and worship his image (cf. Ex. 9:9-11).

Relying on the exodus-based intertextual theme, John offers his worldview to the oppressed Christians in Asia Minor, consisting, as it does, of a symbolic world, which is derived from the Exodus experience of deliverance and liberation. In order to accomplish his goal, John uses a number of exodus symbols and images. He does so not for the sake of secrecy, but rather for the sake of

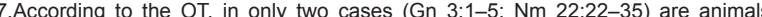
7.According to the $\mathrm{OT}$, in only two cases ( $\mathrm{Gn} 3.1-5, \mathrm{Nm} 22.22-35)$ are animals the impact of their speech being central to the understanding of the texts concerned.

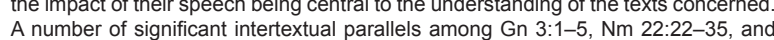
Rv 13 reveal John's exodus intertextuality in connection with Genesis. Although there are partial parallels, the outstanding parallels consist of the following: (1) The ass, the snake, and the beast use interrogatory statements to persuade the listener, though their questions have different rhetorical intent (Gn 3:4-5; Nm 22:28; cf. Rv 13:4). (2) The image of an angel armed with a sword is common to the three stories (Gn 3:24; Nm 22:31; cf. Rv 13:10). (3) The motif of knowledge or wisdom is also common to the three accounts (Gn 3:6. Nm 23.34; Rv 13:18). (4) Obedience to the voice of the is a is associated wh a forign ruler in the story in Numbers and Revelation. (6) The animals speak only by divine initiative (e.g. the divine passive in Rv 13), and have no special powers of their own. (7) In the three texts, it seems that the animals exhibit a deeper understanding of the relationship between the human and the divine than do their human counterparts. (8) The three animals lead people astray. Whereas the snake and the beast do so figuratively, the ass does so literally. (9) The significance

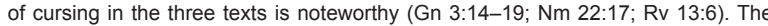
intertextual relationship among the stories of the anomalous animal speech sheds light on the larger patterns of inner-biblical interpretation (see Savran 1994:34, 55).

8. The hymnodic lines are nominal clauses, with attributive modifiers emphasising the point of comparison in the question 'who is like you?'. The first instance is modified simply by a prepositional phrase 'in God'. The phrase, in turn, influences the 'in' phrase, which follows in the next line, i.e. 'among the holy ones', with MT having
a singular word: 'holiness'. The latter might be translated as 'among the holy ones' a singular word: 'holines
(Wevers 1990:231). 
impact. Such symbolism and imagery powerfully convey a sense of evocative and emotive force (Kio 1989:131). In particular, John uses the battle between God and the dragon of Egypt to explain Christ's inaugural victory over the dragon which wages war against the Church. John intends to convince his audience, as the community of the new Exodus, of the fact that God's protection leads them to the asylum in Pella via the Jordan River during the Jewish-Roman War (Rev. 12:6,14; cf. Kraft 1974:264).

The exodus intertextuality is so closely intertwined with the re-creation motif that John clearly compares the status of his audience with that of the Israelites in the Old Testament. If Revelation 12-13 is read in terms of the exodus intertexts, such intertextuality functions as a paradigm for describing God's saving of his own people, as well as his judgement of the oppressors (cf. Du Rand 1996:52-53). The eschatological redemption in terms of the exodus theme for which Christ has worked is so clear in Revelation 12-13 that God's people in Asia Minor, who have already experienced salvation, but who still anticipate its consummation, ${ }^{9}$ are compelled to praise God with great joy.

In summary, in John's use of the exodus theme, he sometimes changes its expression and thought in terms of the archetypal exodus of Christ, in order to make his message fit his audience. In this sense, John understands that the exodus is not so much 'Christocentric' as 'Christotelic', in that the person and works of Christ serve as the starting point for an understanding of the Old and New Testament texts. The exodus theme is so closely intertwined with the re-creation motif that John is clearly able to accentuate the superior status of his audience (as the re-created new Exodus community) to that of the Israelites in the Book of Exodus. If Revelation 12-13 is read from the exodus intertexts, the exodus theme functions as a paradigm for describing God's saving of his own people, as well as his judgement of their oppressors.

\section{CONCLUSION}

The Exodus, which took place at the time of Moses, functions both as an antitype for the pre-Exodus period and as a type for the post-Exodus period. Although the Exodus theme begins with the full-scale exodus from Egypt, the cross and resurrection of Christ, the new Moses and the Son of David play the crucial role of archetype for all exodus events in the progressive redemptive history. Jesus' exodus from Jerusalem (Lk 9:31) is, by way of typological interpretation, the consummated exodus of the new covenantal people at his Parousia in the final stage of redemptive history. Revelation 12-13 expresses the fulfillment of the exodus and provides a foretaste of its consummation on the basis of Jesus' archetypal Exodus. The seven churches in Asia Minor, as a new Exodus and re-created community, must have experienced the new and eschatological exodus from the Roman and the apostate Jewish persecuting power.

\section{REFERENCES}

Aune, D.E., 1998, Revelation 6-16: Word biblical commentary, 52B, Thomas Nelson Publishers, Nashville.

Beale, G.K., 1999, The Book of Revelation, NIGTC, Eerdmans, Grand Rapids.

Beale, G.K. \& McDonough, S.M., 2007, 'Revelation', in G.K. Beale \& D.A. Carson (eds.), Commentary on the New Testament use of the Old Testament, pp. 1081-1161, Baker Academic, Grand Rapids.

Beasley-Murray, G.R., 1997, 'Book of Revelation', in R.P. Martin \& P.H. Davids (eds.), Dictionary of the later New Testament and its developments, pp. 1025-1038, IVP, Downers Grove.

Beckwith, I.T., 1967, The Apocalypse of John: Studies in introduction with a critical and exegetical commentary, Baker, Grand Rapids.

9.The story of salvation, the new Exodus, ends at Revelation 21:8, with its depiction of the new crealion. The desciption of the bide the Lamb is deliberately contrasted to the antichristian to the antichistian city, which is described in Revelation 17 . For this reason, the Book of Revelation reaches its climax as the story of the harlot and the bride. It is, in truth, a tale of two cities (Beasley-Murray 1997:1031).
Boring, M.E., 1986, 'The theology of Revelation: The Lord our God the Almighty reigns', Interpretation 40(3), 257-269.

Broyles, C.C., 1992, 'Moses', in J.B. Green, S. McKnight \& I.H. Marshall (eds.), Dictionary of Jesus and the Gospels, pp. 560562, Inter-Varsity Press, Leicester.

Chevalier, J.M., 1997, A postmodern Revelation: signs of astrology and the Apocalypse, University of Toronto Press, Toronto.

Collins, J.J., 1995, 'The Exodus and biblical theology', Biblical Theology Bulletin 25(4), 152-160.

Daube, D., 1979, The exodus pattern in the Bible, Greenwood Press, Westport.

Dillard, R.B. \& Longman, T., 1994, An introduction to the Old Testament, Zondervan, Grand Rapids.

Du Rand, J.A., 1993, 'A "basso ostinato" in the structuring of the Apocalypse of John?', Neotestamentica 27(2), 299-311.

Du Rand, J.A., 1996, “"... Let him hear what the Spirit says ...”: The functional role and theological meaning of the Spirit in the Book of Revelation', Ex Auditu 12, 43-58.

Du Rand, J.A., 1997, Johannine perspectives. Part 1: Introduction to the Johannine writings, Orion, Johannesburg.

Fretheim, T.E., 1991, 'The plagues as ecological signs of historical disaster', Journal of Biblical Literature 110(3), 385-396.

Garrett, S.R., 1990, 'Exodus from bondage: Luke 9:31 and Acts 12:1-24', Catholic Biblical Quarterly 52(4), 656-680.

Goldsworthy, G., 1991, According to plan, Korea Scripture Union, Seoul.

Hanson, K.C., 1993, 'Blood and purity in Leviticus and Revelation', Listening 28(3), 215-230.

Hoeksema, H., 1974, Behold, He come: An exposition of the Book of Revelation, Reformed Free Publishing Association, Grand Rapids.

Jenkins, F., 1972, The Old Testament in the Book of Revelation, Cogdill Foundation Publications, Marion.

Jordan, J.B., 1996, 'Esther: historical \& chronological comments (II)', Biblical Chronology 8(4), 1-4.

Kariamadam, P., 1997, 'Transfiguration and Jesus' ascended glory', Bible Bhashyam 23(1), 1-13.

Kim, S.Y., 1997, 'Kingdom of God', in R.P. Martin \& P.H. Davids (eds.), Dictionary of the later New Testament and its developments, pp. 629-638, Inter-Varsity Press, Leicester.

Kio, S.H., 1989, 'The Exodus symbol of liberation in the Apocalypse and its relevance for some aspects of translation', Bible Translator 40, 120-135.

Kraft, H., 1974, Die Offenbarung des Johannes, Mohr-Siebeck, Tübingen.

Mazzaferri, F.D., 1989, The genre of the Book of Revelation from a source-critical perspective, De Gruyter, Berlin.

Miligan, W., 1889, The Book of Revelation, Hodder \& Stoughton, London.

Minear, P.S., 1991, 'Far as the curse is found: The point of Revelation 12:15-16', Novum Testamentum 30(1), 71-77.

Mounce, R.H., 1983, The Book of Revelation, Eerdmans, Grand Rapids.

Reddish, M.G., 1995, 'Martyr Christology in the Apocalypse', in S.E. Porter \& C.A. Evans (eds.), The Johannine writings: A Sheffield reader, pp. 212-222, Sheffield Academic Press, Sheffield.

Savran, G., 1994, ‘Beastly speech: Intertextuality, Balaam's ass and the Garden of Eden', Journal for the Study of the Old Testament, 64, 33-55.

Sweet, J.P.M., 1990, Revelation, SCM, London.

Walton, J.H. \& Matthews, V.H., 1997, The IVP Bible background commentary: Genesis-Deuteronomy, IVP, Downers Grove.

Wevers, J.W., 1990, Notes on the Greek text of Exodus, Scholars Press, Atlanta.

Wevers, J.W., 1995, Notes on the Greek text of Deuteronomy, Scholars Press, Atlanta.

White, R.F., 1989, Victory and house building in Revelation 20:121:8: A thematic study, UMI, Ann Arbor. 